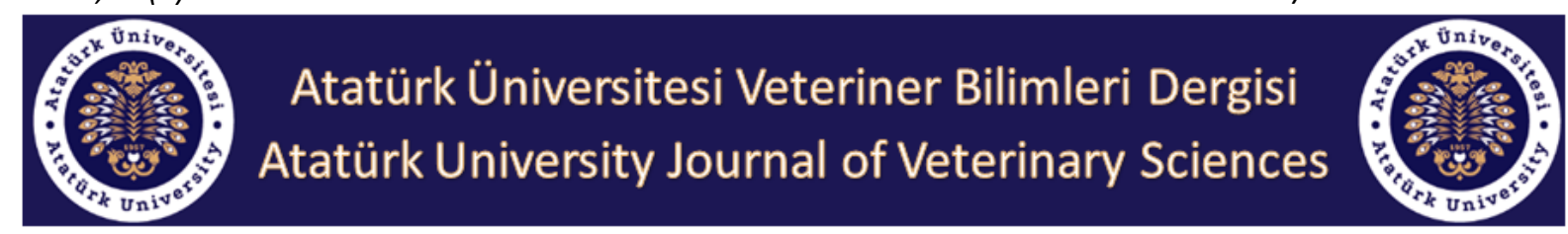

\title{
Yenidoğan Buzağılarda Kolostrum Yönetiminin Önemi
}

\begin{abstract}
Süleyman KOZAT ${ }^{1 \mathrm{a} \otimes}$
1. Van Yüzüncü Yıl Üniversitesi, Veteriner Fakültesi, İç Hastalıkları Anabilim Dalı, Van, TÜRKiYE. ORCID: 0000-0001-5089-2623 a
\end{abstract}

\begin{abstract}
Geliş Tarihi/Received
Kabul Tarihi/Accepted

19.06.2019

Yayın Tarihi/Published

19.03.2019

Bu makaleye atıfta bulunmak için/To cite this article:

Kozat S: Yenidoğan Buzağılarda Kolostrum Yönetiminin Önemi. Atatürk Üniversitesi Vet. Bil. Derg.,14(3): 343-353, 2019. DOI: 10.17094/ataunivbd.541789.

Öz: Kolostrum; yeni doğan buzağıların ilk 28 gününde hastalıklara karşı immunitenin oluşması için annelerinden alması gereken özel ve önemli bir süttür. Buzağılara kolostrum verilmesi neonatal dönemdeki buzağının hayatta kalmasını ve sağlığının korunmasını sağlayan en önemli faktördür. Birçok ülkede buzağı ölümlerinin önemli nedenlerinden biride buzağıların yeterli miktarda kolostrum almamasıdır. Doğan buzağıya doğumdan sonraki ilk 6 saat içinde ilk öğünde buzağı vücut ağırığının yaklaşık \%5'i kadar ve ilk günde ise 3-4 öğünde buzağının vücut ağırlığının \%10’u kadar kolostrum verilmelidir. Neonatal dönemdeki buzağılara belirtilen süreç ve miktarlarda uygun özellikte ve yeterli düzeyde kolostrum verilmemesi durumunda, buzağılarda pasif transferi yetmezliği ortaya çıkmaktadır. Pasif transfer yetmezliği ortaya çıkan yenidoğan buzağılarda antikor alım düzeyinde düşüşler gözlenir. Bu durumda; buzağı ölüm oranında artışa, buzağı sağlı̆̆ı, refahı ve verimliği ile ilişkili birçok kısa ve uzun vadeli kayıplara neden olmaktadır. Bu nedenle neonatal dönemdeki buzağı ölüm oranının düşürülmesi ve hastalıklara karşı direncinin artırıması için başarılı bir kolostrum yönetim programı uygulanmalıdır. Bu çalışmada, etkili bir kolostrum yönetim programının sağlanması ve izlenmesinin temel bileşenlerinin tartışılmasının yanı sıra kolostrojenez süreci gözden geçirilecek ve neonatal dönemde görülen hastalıklar ile kolostrumun önemli bileşenleri arasındaki ilişkiler hakkında detaylı bilgi verilmesi amaçlanmıştır.
\end{abstract}

Anahtar Kelimeler: Buzağı, Kolostrum, Yeni doğan, Yönetim.

\section{The Importance of Colostrum Management in Newborn Calves}

Abstract: Colostrum is a special and important type of milk that should be ingested by newborn calves in order to produce immunity against diseases in the first 28 days of life. Giving colostrum to calves is the most important factor for calf survival and maintaining health. In many countries, one of the most important reason for calf deaths is inadequate intake of colostrum. A newborn calf should ingest approximately $5 \%$ body weight of colostrum in the first 6 hours as first meal and in the first day, this amount should be $10 \%$ of body weight in the first 3-4 meals. Passive transfer failure occurs when the neonatal calves do not ingest adequate and suitable colostrum as stated time and amounts. Besides, passive transfer failure also leads to low intake of antibodies in the calves. This condition leads to increase in death rates, and losses associated with calf health, welfare and productivity. Therefore, a successful colostrum management programme is necessary for decreasing neonatal calf deaths and increasing immunity against diseases. The purpose of this study is to give detailed information related with maintaining and monitoring an effective colostrum programme, as well as discussing the relations between neonatal diseases and important components of colostrum

Keywords: Calf, Colostrum, Management, Newborn. 


\section{Giriş}

Y enidoğan buzağıların hastalık ve ölümleri önemli nedenlerindendir $(1,2)$. Kolostrum yenidoğan yavruların büyümesi ve sağlığı için önemlidir. Kolostrum içerdiği antikor (immunoglobulin) kompleman sistemi sayesinde geniş bir antimikrobiyal etkiye sahiptir ve buzağının kendi bağışıklık sistemi olgunlaşana kadar buzağıda pasif immunite sağlar. Normal süt de yenidoğan buzağılar için ana besin kaynağıdır ve buzağının büyümesigelişmesi için gerekli olan proteinleri, mineralleri, karbonhidratları, yağ asitlerini, büyüme faktörlerini ve bağışıklık modülatörlerini içerir. Ayrıca inek sütünün insanlarda bağışıklık sağlaması için bir araç olabileceği ve çeşitli bakteriyel ve viral antijenlere karşı aşılanmış ineklerden elde edilen "hiperimmun" sütün, patojenlerin bağırsak epiteline invaze olmasını ve istila etmesini önlediği bildirilmektedir (3). Süt ve süt ürünleri hem insan hem de hayvan sağlığı bakımından işlevsel gıdalar olarak kullanılabileceği önerilmektedir $(3,4)$. Neonatal dönem buzağının fizyolojik durumu, sağlık durumu ve hayatta kalması açısında önemli bir dönemdir (5). Buzağı yönetimi uygulamaları buzağı morbiditesini ve mortaliteyi azaltmak için yıllar içinde geliştiyse de, halen neonatal dönemdeki buzağı hastalıklarının \%9 düzeyinde olduğu ve buzağı ishali ile diğer sindirim hastalıklarının buzağı ölümlerinin \%62'sini oluşturduğu bildirilmektedir (6). Sığır kökenli kolostrum yıllardır popüler tıpta bilinmekte ve hem insanların hemde evcil hayvanların bulaşıcı hastalıklarından korunmasında tedavi amacıyla kullanılmaktadır (7).

\section{Buzağılarda Neonatal Dönem}

Buzağılarda neonatal dönem fizyolojik fonksiyonların gelişiminde kritik bir aşamayı oluşturmaktadır. Adaptif (uyum) dönem olarak da bilinen bu aşamada, ekstra-uterine uyumu için buzağının vücut sistemi gerekli değişiklikleri yapmak zorundadır (2). Yenidoğanlar, metabolik olarak intrauterin ortama göre oldukça farklı koşullara sahiptir. Bu nedenle yenidoğanlar özellikle perinatal hastalıklara karşı hassas olup, yüksek mortalite riskiyle karşı karşıyadır (8). Buzağı yetiştiriciliğinin temel amacı, hedef sürü büyüklüğünü sağlayan sağlıklı buzağı yetiştirmektir. Buzağı yetiştirme programının başarısı; buzağı ölüm oranının azaltılması ve günlük canlılık artışının sağlanmasıdır (9). Birçok araştırmacı yenidoğan hastalıklarının teşhis ve tedavisi için doğumun ilk haftasında asit-baz dengesindeki değişiklikler ve pıhtılaşma profilleri üzerinde araştırmalar yapmıştır. Neonatal dönemdeki yavrularda fizyolojik referans değerlerine sahip olmanın öneminin göz önüne alındığı araştırmalarda, özellikle rektal sıcaklık, kalp ve solunum hızları takip edilmiştir. Ayrıca doğumun ilk haftasındaki buzağılarda biyokimyasal parametrelerdeki değişimleri değerlendirmek için; total protein (TP), total kolesterol, trigliseritler, glukoz, esterleşmemiş yağ asitleri (NEFA), üre, kreatinin, kolinesteraz, laktat dehidrojenaz (LDH), hidroksibütirat, glutamat piruvat transaminazlar (GPT), glutat oksatat transaminler (GOT), direk ve indirek bilurubun, magnezyum, demir, potasyum, fosfor, klorür ve sodyum düzeyleri araştırılmıştır (2). Illk kolostrum, yenidoğan buzağıyı bulaşıcı hastalıklara karşı koruyan, annenin lökositlerini de içeren önemli bir besin kaynağı, immunoglobulinler ve diğer önemli bağışıklık faktörlerini de içeren bir özelliğe sahiptir (10).

\section{Kolostrum ve Bileşimi}

Kolostrum, doğumdan sonra salgılanan ilk süt olup yenidoğanın sağlığı için önemli olan immunoglobulinler, sitokinler, besin elementleri ve büyüme faktörlerini içerir $(4,11)$. Kolostrum, buzağılarda bulaşıcı maddelere karşı ilk korunma mekanizmasını sağlar (12). Yaşamın kritik ilk 24 saatinde uygun kalitedeki yeterli kolostrumun alınmasının önemi kanıtlanmıştır (13). Kolostrumun içeriğinde bulunan immunoglobulinler annenin 
kanından meme bezlerine taşınması, doğumdan birkaç hafta önce başlar ve doğumdan 1-3 gün önce en yüksek seviyesine ulaşır (14). Doğum yapan inekler doğumdan sonraki ilk 7 gün boyunca kolostrum salgılar. Sığır kolostrumunda, immunoglobulinler total protein içeriğinin \%70-80'ini oluştururken, normal sütte total proteinin sadece \%1-2'sini oluşturmaktadır (12). Kolostrumun yüksek düzeyde immunoglobulin içermesi yenidoğan buzağıda pasif bağışıklığın sağlanması ve bağırsak düzeyinde lokalize olmasında önemli rol oynar (13). İmmunoglobulinler memeli kan dolaşımında yabancı antijenlere tepki olarak lenfositler tarafından üretilen, vücudu patojenik organizmalardan koruyarak ve hastalıklara karşı direnç sağlayarak immunolojik mekanizmada önemli rol oynayan plazma proteinleridir (12). Buzağıdaki immunoglobulin düzeyi, alınan kolostrum miktarı ve kolostrumdaki Ig konsantrasyonuna bağlıdır (13). Kolostrum yönetimi, buzağı sağığını ve sürü büyüklüğünü korumada en önemli yönetim faktörüdür (15). Annenin immunoglobulinler tablosu ve immunolojik hafızası, anneden yavrulara ya gebelik döneminde fetüse plasenta yoluyla ya da yenidoğanlara memeden gelen kolostrum yoluyla gastrointensital sisteme geçer (4). Ruminantlar ve tek tırnaklı hayvanlarda immunoglobulinlerin plasenta yoluyla yavruya geçmesi mümkün değildir $(8,12)$. Buzağılarda immünoglobulinlerin (Ig), diğer kolostral kompanentlerle birlikte sindirim sisteminden absorbsiyonu, pasif transfer immünitesi olarak tanımlanır $(4,12)$. Bu tür hayvanların yavruları hemen hemen hiç antikor almadan doğar ve dolayısıyla bağışıklık sistemi anneden alınan kolostruma bağlıdır. Kolostrum, neonatal dönemdeki buzağılarda immun fonksiyonlara destek görevi yapan birçok bileşiği içerir (16). İneklerde kolostral immunoglobulinin \%90'ından fazlası immunoglobulin G (IgG) olup ve doğumdan sonra ilk sağımda ortalama konsantrasyonu yaklaşık 60 gr/L'dir. IgG konsantrasyonu, 12. süt sağımında keskin bir düşüşle (18) yaklaşık $1 \mathrm{gr} / \mathrm{L}^{y} y e$ düşer ve normal sütte 0.5 gr/L'ye kadar iner (4). Kolostrum immunoglobulin $\mathrm{M}$
(IgM), IgG, immunoglobulin A (IgA), immunoglobulin D (IgD) ve immunoglobulinE (IgE)' yi içerir. Sığır kolostrumunda mevcut olan toplam immunoglobulinlerin \%85 ile \%90'ını içeren $\operatorname{lgG}$, doğumdan önce meme bezinde biriken meme epiteli boyunca kandan transfer edilmektedir (11). Kolostrumun bileşimde Ig'ler sırasıyla \%85-90 oranında IgG, \%7-10 IgM ve \%5 IgA gruplarından oluşmaktadır. Kolostrumdaki Ig düzeyleri bireysel olarak değişmekle birlikte ortalama kolostral IgG, IgM ve IgA düzeyleri sırasıyla 7500, 440 ve $490 \mathrm{mg} / \mathrm{dl}$ olarak bildirilmiştir (17). Kolostrumdaki IgG konsantrasyonu buzağı sağlığı ile doğrudan ilgilidir ve bu nedenle kaliteyi belirlemede önemli ölçüttür (15). Sığırlarda kaliteli bir kolostrum için IgG konsantrasyonu $50 \mathrm{~g} / \mathrm{L}$ olarak bildirilmiştir (11). Bu antikor; opsonizasyon, kompleman fiksasyon, patojen yapışmasının önlenmesi, bakteriyel metabolizmanın engellenmesi, bakteriyel aglütinasyon, virüslerin ve toksinlerin nötralizasyonu gibi çeşitli fonksiyonlara sahiptir (18). Sığır kolostrumundaki ana immunoglobulin $\mathrm{G}$; $\lg _{1}$ ve $\lg _{2}$ olmak üzere iki temel alt sınıfa ayrılmakta (12) ve immunoglobulin $G_{1}$ tüm immunoglobulinlerin yaklaşık \%50-80'ini oluşturmaktadır Kolostrumdaki $\operatorname{lgG}_{1}$ konsantrasyonu, meme alveoler epitel hücrelerinin üzerindeki reseptörler tarafından kolaylaştırılır. Glandüler epitel hücreleri laktasyonun başlangıcında bu reseptörü eksprese eder. Değişmiş ekspresyon büyük olasılıkla artan prolaktin konsantrasyonuna cevap olarak ortaya çıkar (14). Sütteki $\operatorname{lgG}_{1}$ konsantrasyonu genetik ve hormonal etkiler, yaş, beslenme durumu ve ineğin laktasyon evresi gibi birçok faktörden etkilenir (13). Bunlara ek olarak; laktasyon sayısının, özellikle ilk üç laktasyonun $\operatorname{lgG}_{1}$ konsantrasyonunu ve kütlesini etkileyen en önemli faktörler olduğu bildirilmiştir (12). İmmünoglobülin transferini etkileyen faktörler kolostrum alımının zamanlaması, kolostrum uygulamasının yöntemi, alınan kolostrumun immunoglobulin konsantrasyonu, annenin ırkı ve yaşıdır. Bu faktörler çoğunlukla buzağıdaki pasif aktarım üzerinde etkilidir (14). Kolostral 
immunoglobulinlerin yetersiz transferine sahip buzağılarda, ilk 12 haftada mortalite riskinin arttığı ve canlı ağırlık artış oranının düştüğü bildirilmiştir (19).

Tablo 1. Kolostrumun biyolojik olarak aktif bileşenleri (17).

Table 1. Biologically active components of colostrum (17).

\begin{tabular}{lcc}
\hline $\begin{array}{c}\text { Antimikrobiyel } \\
\text { faktörler }\end{array}$ & $\begin{array}{c}\text { Büyüme faktörleri } \\
\text { ve hormonlar }\end{array}$ & Besinler \\
\hline $\begin{array}{l}\text { Immunoglobül } \\
\text { inler }\end{array}$ & $\begin{array}{c}\text { Insülin-benzeri } \\
\text { büyüme faktörü }\end{array}$ & Yağ \\
Lizozim & $\begin{array}{c}\text { Epidermal büyüme } \\
\text { faktörü } \\
\text { Transforming } \\
\text { büyüme faktörü }\end{array}$ & Laktoz \\
Laktoperokinler & $\begin{array}{c}\text { Büyüme hormonu } \\
\text { Sitokinler }\end{array}$ & Vitaminler \\
\hline
\end{tabular}

Tablo 2. Süt ve Kolostrum Kompozisyonu (20).

Table 2. Composition of bovine colostrum and mature milk (20).

\begin{tabular}{lcc}
\hline Besin & Kolostrum & $\begin{array}{c}\text { Doğum sonrası } \\
\text { 14. gündeki süt }\end{array}$ \\
\hline TP (\%) & 17.12 & 3.57 \\
Yağ(\%) & 4.69 & 5.26 \\
BE (Mj/L) & 6.0 & 2.8 \\
HP (gr/L) & 133 & 32 \\
Ig G (gr/L) & 81 & $<2$ \\
LCF (gr/L) & 1.84 & 0.34 \\
Transferrin (gr/L) & 0.55 & 0.21 \\
GGT (U/L) & 509 & 52 \\
ALP (U/L) & 19 & 4 \\
AST (U/L) & 1.5 & 0.1 \\
TNF $(\mu g / L)$ & 5 & $<2$ \\
İnsülin $(\mu g / L)$ & 65 & 1 \\
Glukagon( $\mu g / L)$ & 0.16 & 0.01 \\
Prolaktin $(\mu \mathrm{g} / \mathrm{L})$ & 280 & 15 \\
BH $(\mu \mathrm{L} / \mathrm{L})$ & 1.4 & $<1$ \\
IGF-I $(\mu \mathrm{g} / \mathrm{L})$ & 310 & $<2$ \\
IGF-II $(\mu \mathrm{g} / \mathrm{L})$ & 150 & - \\
\hline
\end{tabular}

ALP: Alkaline fosfataz, AST: Aspartat amino transferaz, BE: Brüt enerji, Ig G: Immunoglobulin G, GGT: Gamma glutamiltransferaz, HP: Ham protein, LCF: Laktoferrin, TP: Total protein, IGF-I: Insülin benzeri büyüme faktör-I, IGF-II: Insülin benzeri büyüme faktör-II, TNF: Tumör Nekroz Faktör, BH: Büyüme hormonu
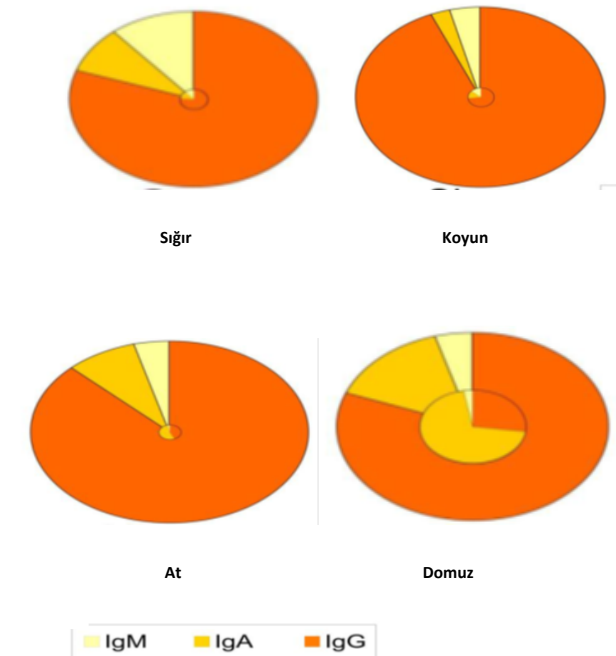

Şekil 1. Sığır, koyun, at ve domuz kolostrumları (dış daire) ve sütlerindeki (iç daire) IgG, IgA ve IgM düzeylerinin oransal dağılımı (21).

Figure 1. Relative distribution of $\lg G, \lg A$ and $\lg M$ in colostrum (outer circle) and in milk (inner circle) of cattle, sheep, horse and pig (21).

\section{Kolostral Antikorlar}

İmmünoglobulinler, sütte ve kolostrumda bulunan immunolojik aktivitenin önemli bir bileşenini oluşturmaktadır (21). Kolostral antikorlar, fagositoz ve patojenlerin lökositler tarafından öldürülmesini tetikleyebilir ve enfeksiyon oluşumunda kritik bir adım olan patojenin epitel astarına bağlanmasını önleyebilir (22). Buzağı serumu içindeki yüksek seviyeli kolostral immunoglobülinler, buzağıların yaşamlarının ilk haftalarında sağlıklarını ve büyümelerini sağlamasının yanısıra gelecekte dişi buzağıların damızlık kullanım şansını artırmaktadır (23). İmmünoglobülinler, meme epitel hücrelerinde reseptör aracılı mekanizmalar ile taşınır ve emilim sırasında meme bezinden çıkar (21). Sığır serumu ve laktal salgıları genel olarak IgG, IgM ve IgA'yı kapsar. İmmünoglobulinler, seçici olarak serumdan meme bezinin içine transfer olur ve ilk kolostrumda çok yüksek konsantrasyonlarda immunoglobulin düzeylerine $(40 \pm 200 \mathrm{mg} / \mathrm{ml})$ ulaşır (3). Anne sütü yenidoğan yavruları mikrobiyal patojenlere karşı korur $(7,12)$. Doğumdan sonra 12 saat içinde kolostrum almak önemlidir. Aksi takdirde yeni doğmuş buzağılarda ilk haftalarda yüksek mortalite 
ve düşük kilo alımı gözlenebilir. Nitekim IgG düzeyi 10 gr/L'den düşük olan yenidoğan buzağılarda mortalite oranlarının yüksek ve pnömoni riskinin iki kat daha fazla olduğu bildirilmiştir (12). Kolostrumdaki immunoglobulinler, annenin bağışıklık sisteminden bağımsız değildir (21). Buzağıların ilk 14 günündeki ishal ve perinatal enfeksiyonlardan dolayı oluşan ölümlerden dolayı oluşan ekonomik kayıpların küçümsenemeyecek düzeyde olduğu bildirilmiştir (22). Gebe inek, koyun veya domuzun Enterotoksijenik Escherichia coli'ye (ETEC) ve bağırsak virüslerine karşı aşılanması (24) yenidoğanların immunizasyonunda koruma sağladığı ifade edilmiştir (21). İnaktive edilmiş rotavirüsle aşılanan kısrakların taylarında morbidite \%30 iken, aşılanmamış kısrakların taylarında morbidite \%80'lere ulaşmıştır (4). Kolostrum ile beslenen buzağılarda, beslenmeyenlere göre BRV ile ilişkili ishal vakaları istatistik olarak önemli derecede daha az gözlenmiştir (25). İmmünolojik olarak aktif hücreler ve laktoferrin gibi çözünebilir mediatörler anneden yavruya kolostrum yoluyla transfer edilmektedir $(8,12)$.

\section{Kolostrumun Verilme Zamanı ve Miktarı}

Anne sütündeki immunoglobulinler; anneden yenidoğana pasif bağışıklık transferi ve yenidoğanın olgunlaşmamış bağışıklık sistemi arasındaki ilişkiyi etkiler. Yüzyıllar boyunca maternal immun durum ile yenidoğanın immunolojik korunması ve gelişimi arasındaki bağlantıya önem verilmekle birlikte ancak on dokuzuncu yüzyılın sonlarına doğru bilimsel olarak ifade edilmiştir (21). Yenidoğanın hayatta kalması sıklıkla pasif immunizasyon derecesi ile pozitif bir korelasyon göstermekte ve yenidoğan yavrunun dolaşımdaki immunoglobulinleri, özellikle IgG, çevresel antijenlere karşı konakçı savunmasında genel olarak önemli bir rol üstlenmektedir $(6,26)$. İneklerin syndesmochorial plasentası, maternal endometriyum ile fetal trofektoderm arasında maternal ve fetal kan kaynaklarını ayıran uterusa sahip olmaları, immunoglobulinlerin geçişini önleyen bir sinsityum oluşturur $(12,14)$. Sonuç olarak, buzağılar agamaglobülinemik olarak doğar ve pasif bağışıklık sağlamak için gerekli olan yeterli miktarda kolostral immunoglobulin almaları ve bunların emiliminin sağlanması gerekir $(14,27)$. Yenidoğan buzağıların yaşamın ilk 28 gününü kapsayan Neonatal periyotta hastalıklara karşı koruyucu immünitenin sağlaması ve kendi immün sistemlerinin aktifleşmesine kadar geçen süreçte tek yolu kolostrumun alınması ve absorbsiyonudur (12). Yeni doğmuş bir buzağıya, normal serum immunoglobulin G seviyesi $10 \mathrm{~g} / \mathrm{L}$ olacak şekilde minimum 2 litre kolostrum (120 g immunoglobulin'e eşdeğer miktarda) verilmelidir $(4,23)$.

Kolostrumun, bileşimindeki çeşitli immunoglobulinlerden dolayı buzağıyı enfeksiyöz ajanlara karşı koruyan ilk savunma mekanizması olduğu belirtilmektedir (27). Ayrıca kolostrum buzağıya enerjide sağlamaktadır (12). Yeni doğan buzağılarda kolostrum alınmasını takiben lgG'ler seçici olmayan pinositoz mekanizması ile barsak epitel hücreleri tarafından emilerek ekzositoz ile lenfatik ve daha sonra torasik duktus aracılığı ile kan dolaşımına aktarılır $(12,28)$. Bu nedenle epitelyum hücreleri ilk 4 saat içinde bütün IgG'ler değişikliğe uğramadan maksimum oranda absorbe edilir. Kolostrum alımı ne kadar erken olursa buzağı kanında o kadar fazla antikora rastlanır. Çünkü yeni doğan buzağıların barsak epitel hücreleri henüz olgunlaşmadığından yaşamın ilk birkaç saatinde veziküllü ve vakuol yapıdadır. Buzağının immunoglobülin emme yeteneği yaşla birlikte hızla azalır. Bu nedenle buzağıların doğumdan sonraki ilk 2 saat içinde kolostrum tüketmeleri önerilir (29). Kolostrumun kalitesinin hayvandan hayvana değiştiği ve inek kolostrumunun düvelere göre daha yüksek antikor konsantrasyonuna sahip olduğu bildirilmiştir (13). Kolostrumun erken verilmesinin gerekliliğinin bir diğer nedeni de bileşenlerinin seviyesinin ve besleyici değerinin doğumdan sonra hızla azalmasıdır $(12,28)$. Buzağının ihtiyaç duyduğu kolostrum miktarının belirlenmesi ve ilk 3 günde ne kadar kolostrum verileceğinin hesaplanması amacıyla, buzağının canlı ağırlığı dikkate alınmalıdır. Son 
yıllarda yapılan çalışmalarda ilk beslemede canlı ağırlığın \%10-12'si kadar kolostrumun verilmesi gerektiği rapor edilmiştir. Devam eden günlerde ise canlı ağırlığın \%10'unu geçmeyecek şekilde kolostrum veya geçiş sütü iki veya üç öğünde verilmelidir (12,19). Yenidoğan buzağıya ilk kolostrum verilmesinin üzerinden 12 saat geçmeden tekrar verilmesi Ig seviyelerinde 24-48 saat boyunca artışlar yaşanmasına neden olduğu bildirilmiştir $(12,28)$. Pek çok araştırmada yenidoğan buzağılarda hastalıklara karşı koruyan farklı serum immunoglobulin konsantrasyonları açıklanmıştır. Serum Ig konsantrasyonu $10 \mathrm{gr} / \mathrm{L}$ 'den az olduğunda 24 saatlik buzağı yaşamında pasif transfer yetmezliği geliştiği bildirmişlerdir $(14,30,31)$. Serum IgG düzeyi $10 \mathrm{~g} / \mathrm{L}$ 'den daha az olan buzağılarla ilgili bir başka çalışmada da buzağıların, serum IgG düzeyi 10 g/L'den daha yüksek olan buzağılara göre daha fazla hastalık riskinin olduğu bildirilmiştir (32). Ruminantlarda, yeni doğanların immunoglobulinlerinin pasif transferinin yetmezliği çeşitli hastalıklara karşı direncin düşük olmasına neden olur. Buzağı morbidite/mortalitesi ile yenidoğan buzağıların azaltılmış maternal immunoglobulin transferi arasında yüksek bir ilişki vardır. Buzağılarda morbidite/mortalite artışı performans düşüklüğüyle birlikte yüksek üretim maliyeti ve düşük karlılığa neden olmaktadır (33).

\section{Kolostrum İkame Besinleri}

Kolostrum eşdeğeri besin maddeleri, yeterli kolostrum bulunmadığında veya pastörize edilmemiş kolostrum yoluyla bulaşabilecek hastalıkların bulaşmasını önlemek için kullanılır. Neonatal dönemdeki buzağılarda pasif immunitenin sağlanması ya kolostral immunoglobulinlerin alınması ya da kolostrum eşdeğerleri ile sağlanabilir (27). Avrupa'da sığır kolostrumundan hazırlanan çok sayıda kolostrum muadili ürün bulunmaktadır. Beşeri hekimlikte hastalığa neden olan dokulardaki spesifik hedef hücreler ile etkileşime girme, ilaçlar dahil toksik maddeleri etkisiz hale getirme, kanser tanı ve tedavisi için antikorların üretilmesi araştırılmıştır.
Buna ek olarak bu antikorlar özellikle bağışıklık yetersizliği olan hastalarda, bulaşıcı hastalıkların tedavisi için pasif immunoterapide de kullanılmaktadır (7). İmmunoglobulin izolasyonu ve saflaştırılması için 1980'lerden bu yana bir dizi patentli yöntem geliştirilmiştir. Kolostral veya peynir altı suyu, ultrafiltrasyon (UF) veya UF ve kromatografi kombinasyonları bu yöntemlerden bazılarıdır (3). Maternal kolostrum (MC) alınamadığı durumlarda ticari olarak temin edilebilen kolostrum replasmanları (CR) yönetsel kolaylık sağlamak, pastörize edilmemiş kolostrum yoluyla bulaşabilen hastalıkların bulaşmasını önlemek (27) ve eradikasyon programlarında kalite tutarlılığını sağlamak için yaygın olarak kullanılmaktadır (34). Endüstriyel olarak üretilen yüksek kaliteli bir kolostrumun; IgG konsantrasyonunun 50 mg/ml'den daha yüksek, total bakteri sayısının 100,000 cfu/ml'den ve koliform sayısının $10.000 \mathrm{cfu} / \mathrm{ml}$ 'den daha düşük oranda olması gerektiği bildirilmiştir $(34,35)$. Bazı çalışmalar, kolostrum yerine geçen bazı ticari ürünlerle beslenmenin daha başarılı sonuçlar verdiğini göstermiştir (34). Ayrıca kolostrumla beslenmeyen buzağıların beslenenlere göre daha erken zamanda IgG ve IgA üretimini tetikledikleri saptanmıştır. Peynir altı suyu, kan/serum, normal süt ve yumurtadan elde edilen ticari olarak kurutulmuş kolostrum ek/ikame ürünleri olarak kolostrumun yerine kullanılabilmektedir. Bu ürünler maternal kolostrumla birlikte buzağıda istenilen düzeyde antikor sağlayarak pasif transferin desteklenmesi ve kolostrumdan patojenlerin bulaşma riskinin azaltılması amacıyla kullanılması durumunda başarılı sonuçlar alınabildiği tespit edilmiştir. Kolostrum yerine geçen bu ek ikame ürünleri kolostrumla kıyaslandığında avantaj ve dezavantajları bulunmaktadır. Türetilmiş kolostral immunoglobulinler, çeşitli mekanizmalar tarafından yenidoğan immunitesini baskılayabilir. İmmün sistemin kolostral türevli immunoglobulinler tarafından baskılanması mekanizması, antijene özgü olabilir veya antijene özgü olmayabilir (27). Bu ürünlerde IgG seviyelerinin maternal kolostruma 
oranla daha sınırlı elde edilebilmesi ve lezzetlerinin de iyi olmaması olumsuz yanlarını oluşturmaktadır. Kolostrumun dışındaki kaynaklardan hazırlanan ek/ikame ürünlerde tripsin inhibitörleri yüksek oranda bulunmayabilir. Bu nedenle bu ürünlerdeki IgG'ler proteolitik bozulmaya ve yetersiz absorbsiyona daha duyarlı olabilir (14). Rotavirüs veya ETEC suşlarının neden olduğu ishalli hastalıkları önlemek için yenidoğan yavrularda kolostral peynir altı suyu bazlı veya normal peynir altı suyu bazlı çeşitli antikor preparatları yem takviyeleri veya kolostrum ikameleri olarak kullanılabilmektedir. Kolostrumdan yapılmış immunoglobulin preparatları bağışıklık sütü olarak adlandırılmaktadır (36). Tipik bir bağışıklık sütü suda çözülebilen susuzlaştırılmış peynir altı suyu tozu, yağsız süt, bazı immunoglobülinler ve total protein içeriğinin \%30-50'si olarak formüle edilebilir. Bir immun süt preaparatı olan ticari bağışıklık süt ürünleri rotavirüslere karşı aktif dondurulmuş ve liyofilize sığırların antimikrobiyal etkisinin buzağılar üzerinde kolostrumdan farklı olmadığı gösterilmiştir (4). Son zamanlarda yapılan çok sayıda çalışmada sığır hiperimmun kolostrum preparatının oral uygulamasının insanlarda ve hayvanlarda birçok bulaşıcı madde ve hastalıklara karşı etkili koruma sağladığı bildirilmiştir (34). Ayrıca yeni doğan buzağılara kolostrum yerine intravenöz olarak verilen plazma uygulamasının kolostrum veya kolostrum replasmanı verilen buzağılara göre, immunoglobulinlerin yeterli oranda transferinin yapılamadığı ve ölüm oranının daha yüksek olduğu gözlenmiştir (27). Kolostrum yerine geçebilen ikame maddelerin avantaj ve dezavantajları aşağıdaki şekilde özetlenir (37):

\section{Kolostrum İkame Ürünün Avantajları}

- Hazır ve uygun şekilde paketlenmiş ve kullanıma hazır,

- 2 litre suda karışım kolaylığı

- Bakteriyel kontaminasyon veya bulaşıcı hastalık transferi yok,
- Yeterli immunoglobulin seviyeleri elde edilebilir,

- Buzağı sağlığı tehlikeye girmez.

\section{Kolostrum ikame ürünün dezavantajları}

- İmmünglobulin düzeyleri kolostrumdan daha düşük,

- Ürünün besin takviyesi eklenmiş olmasına rağmen, kolostrum kadar besleyici değil,

- Spesifik olmayan bağışıklık faktörleri ve bağışıklık hücreleri mevcut değildir,

- Yüksek karbonhidrat içeriği, özellikle kolostrum ile karıştırıldığında hızlı mide boşalmasına neden olabilir. Bu durum enterotoksemi riskini artırabilir.

\section{Neonatal Buzağılarda Görülen Hastalıkların Kolostrumla İlişkisi}

Neonatal dönemde buzağılarda \%20'lik bir kayıp hayvancılık sektöründe \%40'lık bir kar kaybına neden olur. Bu dönemdeki buzağı ölümlerine neden olan faktörler, enfeksiyöz ve enfeksiyöz olmayan nedenler olarak iki kısımda incelenebilir (1).

\section{Enfeksiyöz Nedenler}

Neonatal dönemde buzağılarda verim ve ölüm kayıplarında gastrointestinal ve solunum sistemi hastalıkları önemli bir yer teşkil etmektedir. Bu dönem aralığındaki buzağıların gastrointestinal hastalıklarından ishale neden olan hastalıklar ve solunum sistemi hastalıkları olarak pnömonilere neden olan hastalıklar önemli rol oynamaktadır (38). İmmünoglobulinler virüsler, protozoalar, bakteriler ve toksinler gibi belirli antijenleri spesifik olarak tanıyan ve bunlara bağlanan immun tepkinin önemli bir parçası olarak işlev gören plazma hücreleri tarafından üretilen glikoprotein molekülleridir (39). Buzağı yetiştiriciliğinin en kritik dönemi, yüksek hastalık ve ölüm riski nedeniyle yaşamın ilk ayıdır (12, 40). İshal yenidoğan buzağılarda önemli bir hastalıktır ve hem sütçü hem de etçi buzağılardaki ekonomik kayıpların en önemli nedenidir $(12,40)$. Yenidoğan buzağılarda; rotavirüs, coronavirüs, Enteropatojenik 
E. coli, Salmonella türleri ve kriptosporidiumlar başlıca enfeksiyöz ajanlarıdır $(40,41)$. Hastalığın insidansı ve ciddiyeti, bir buzağının aldığı kolostrum miktarına ve IgG seviyesine oldukça bağlıdır (12). Neonatal buzağı pnömonilerin etiyolojlerinde rol olan bakteriyel etkenler; Pasteurella multocida, Pasteurella hemolytica, Streptococci, Pseudomonas aeuroginosa, Mycoplasma bovis, Corynaebacterium pyogenes ve E. coli'dir (40). Viral etkenler ise; Herpesvirus, Pestivirüs, Coronavirus, Adenovirüs, $B H V-1$, Reovirüs, Rinovirüs ve Parainfluenza-3 (P1-3) virüslerdir (1).
Hayvanlarda düşük Ig konsantrasyonları ile hastalıklar arasındaki ilişkiyi ortaya koymak için pek çok çalışma yürütülmüştür $(12,32)$. İmmünoglobulinler; pnömonik patojenlerin tanımlanması, nötralizasyonu, opsonizasyonu ve doğrudan parçalanmasında özellikle etkili olduğu bildirilmiştir (42). Buzağılarda yaşamın ilk haftalarında yetersiz kolostrum alımına bağlı oluşan yetersiz immuniteden dolayı solunum yolu enfeksiyonlarına duyarlılığın ve ölüm riskinin arttığı saptanmıştır (12).

Tablo 3. Farklı hastalıklara sahip buzağılar arasındaki serum total protein ve IgG'nin karşılaştırılması (42).

Table 3. Comparison of serum total protein and IgG between calves with different morbidity (42).

\begin{tabular}{lcccc}
\hline Parametre & Total Protein g/dl & Ortalama & Ig G g/dl & Dağılım aralığı \\
\hline Sağlıklı Buzağı & $6.42 \pm 0.62$ & $5.2-7.3$ & $3.904 \pm 0.61$ & $2.950-5.000$ \\
İshalli Buzağı & $6.33 \pm 0.69$ & $4.9-8.0$ & $3.561 \pm 0.83$ & $2.000-5.000$ \\
Pnömonili Buzağı & $6.40 \pm 0.63$ & $5.6-8.0$ & $3.547 \pm 0.80$ & $2.100-5.000$ \\
Pnömoni + İshalli Buzağı & $6.45 \pm 0.59$ & $5.5-7.5$ & $3.770 \pm 0.74$ & $2.600-5.000$ \\
\hline
\end{tabular}

\section{Enfeksiyon Olmayan Sebepler}

\subsection{Doğum Dönemi}

Mevsimler ile yavru ölümleri arasında bir ilişkinin olduğu, kış aylarında kolostrum immunoglobulin konsantrasyonlarının ilkbahar ve yaz aylarına gore daha düşük olduğu gözlenmiştir. Kış aylarında ölüm oranı \%69.6, ilkbahar ve yaz aylarında ise $\% 5.97$ düzeyinde saptanmıştır $(8,12)$.

\subsection{Doğum ve Doğumsal Problemler}

Gebe ineklerde distosi (güç doğum) yenidoğanlarda ölüm oranını arttırır. Bunun yanısıra cinsiyet (erkek) ve doğum ağırlığı buzağılarda ölü doğum oranını artıran diğer önemli faktörlerdir (8).

\section{Barınma ve Bakım}

Buzağı barınaklarının; yetersiz havalandırma koşulları, birim alandaki aşırı hayvan yoğunluğu, temizlik ve dezenfeksiyon yetersizlikleri yüksek buzağı ölümlerine yol açan solunum sistemi rahatsızlıklarının önemli nedenleridir Hayvan bakıcıları buzağıların yaşamının ilk 6-8 saatinde maksimum düzeyde kolostrum almalarını sağlamalıdır (8). Eğer bu süre içinde buzağının kolostrumla beslenmesi ertelenirse, buzağılarda hipo veya agamaglobülinemi gelişir (12). Emzirme uygulaması biberonla beslenme ile kıyaslandığında, kolostral immunoglobulin emiliminin daha yüksek olduğu ve bu nedenle, buzağının annesini doğumdan sonraki ilk iki gün emiliminin sağlanması tavsiye edilmektedir (8).

\section{SONUÇ}

Buzağı yetiştiriciliğinde neonatal dönem oldukça önem bir periyottur. Buzağı yönetimi uygulamalarında büyük gelişmeler olmasına ragmen, neonatal dönemde buzağıların hastalıklara yakalanma riski ve mortalite oranın \%9 civarında olduğu rapor edilmektedir. Neonatal dönemdeki gerek buzağı ölümleri ve gerekse buzağılardaki verim kayıplarına bağlı oluşan ekonomik kayıplar hayvancılık sektöründe önemli yer teşkil etmektedir. Bu dönemde yenidoğan buzağıları hastalıklara karşı korumak ve yaşam sürecinde etkin bir canlı ağırlık artışının sağlanması için kolostrum veya kolostrum 
ikame besinleri buzağılara zamanında ve yeterli miktarda verilmesi önemlidir.

\section{Çıkar Çatışması}

Bu derlemede yazarlar arasında çıkar çatışması olmadığını beyan ederim.

\section{KAYNAKLAR}

1. Singh DD., Kumar M., Choudhary PK., Singh HN., 2009. Neonatal calf mortality an overview. Intas Polivet, 10, 165-169.

2. Piccione G., Casella S., Pennisi P., Giannetto C., Costa A., Caola G., 2010. Monitoring of physiological and blood parameters during perinatal and neonatal period in calves. Arq Bras Med Vet Zootec, 62, 1-12.

3. Korhonen H., Marnila P., Gill HS., 2000. Milk immunoglobulins and complement factors. Br J Nutr, 84, 75-80.

4. Lilius EM., Marnila P., 2001. The role of colostral antibodies in prevention of microbial infections. Curr Opin Infect Dis, 14, 295-300.

5. Diesch TJ., Mellor DJ., Stafford KJ., Ward RN., 2004. The physiological and physical status of single calves at birth in a dairy herd in New Zealand. N Z Vet J, 52, 250-255.

6. Baumrucker CR., Burkett AM., Magliaro-Macrina AL., Dechow CD., 2010. Colostrogenesis: Mass transfer of immunoglobulin G1 into colostrum. J Dairy Sci, 93, 3031-3038.

7. Struff WG., Sprotte G., 2007. Bovine colostrum as a biologic in clinical medicine: review. Int J Clin Pharmacol Therapeut, 45, 193-202.

8. Kozat S., 2018. Hypothermia in newborn calves. J Ist Vet Sci, 2, 30-37.

9. Sherwin V., Hudson C., Henderson A., Breen J., 2016. Measuring health and performance in preweaning dairy calves. In Practice, 38, 113122.

10. Johnson JL., Godden SM., Molitor T., Ames T., Hagman D., 2007. Effects of feeding heat-treated colostrum on passive transfer of immune and nutritional parameters in neonatal dairy calves. $\mathrm{J}$ Dairy Sci, 90, 5189-5198.
11. Conneely M., Berry DP., Sayers R., Murphy JP., Lorenz I., Doherty ML., Kennedy E., 2013. Factors associated with the concentration of immunoglobulin $\mathrm{G}$ in the colostrum of dairy cows. Animal, 7, 1824-1832.

12. Gökçe E., Erdoğan HM., 2013. Neonatal buzağılarda kolostral immunoglobulinlerin pasif transferi. Turkiye Klinikleri J Vet Sci, 4, 18-46.

13. Miyazaki T., Okada K., Miyazaki M., 2017. Neonatal calves coagulate first-milking colostrum and produce a large curd for efficient absorption of immunoglobulins after first ingestion. J Dairy Sci, 100, 7262-7270.

14. Weaver DM., Tyler JW., Van Metre DC., Hostetler DE., Barrington GM., 2000. Passive transfer of colostral immunoglobulins in calves. J Vet Intern Med, 14, 569-577.

15. Godden, S., 2008. Colostrum management for dairy calves. North Am Food Anim Pract, 24, 1939.

16. Nagy DW., 2009. Resuscitation and critical care of neonatal calves. Vet Clin North Am Food Anim Pract, 25, 1-11.

17. Godson DL., Acres SD., Haines DM., 2003. Failure of passive transfer and effective colostrum management in calves. Large Anim Vet Rounds, 3, 1-6.

18. Korhonen H., Marnila P., Gill HS., 2000. Milk immunoglobulins and complement factors. $\mathrm{Br}$ J Nutr, 84, 75-80.

19. Chigerwe M., Tyler JW., 2010. Serum IgG concentrations after intravenous serum transfusion in a randomized clinical trial in dairy calves with inadequate transfer of colostral immunoglobulins. J Vet Intern Med, 24, 231-234.

20. Blum JW., Hammon H., 2000. Colostrum effects on the gastrointestinal tract, and on nutritional, endocrine and metabolic parameters in neonatal calves. Livest Sci, 66, 151-159.

21. Hurley WL., Theil PK., 2011. Perspectives on immunoglobulins in colostrum and milk. Nutrients, 3, 442-474.

22. Lakritz J., Tyler JW., Hostetler DE., Marsh AE., 
Weaver DM., Holle JM., Denbigh JL., 2000. Effects of pasteurization of colostrum on subsequent serum lactoferrin concentration and neutrophil superoxide production in calves. Am J Vet Res, 61, 1021-1025.

23. Furman-Fratczak K., Rzasa A., Stefaniak T., 2011. The influence of colostral immunoglobulin concentration in heifer calves' serum on their health and growth. J Dairy Sci, 94, 5536-5543.

24. Saif LJ., Smith KL., Landmeier BJ., Bohl EH., Theil KW., Todhunter DA., 1984. Immune response of pregnant cows to bovine rotavirus immunization. Am J Vet Res, 45, 49-58.

25. Lemaire M., Weynants V., Godfroid J., Schynts F., Meyer G., Letesson JJ., Thiry E., 2000. Effects of bovine herpesvirus type 1 infection in calves with maternal antibodies on immune response and virus latency. J Clin Microbiol, 38, 18851894.

26. Sangild PT., 2003. Uptake of colostral immunoglobulins by the compromised newborn farm animal. Acta Vet Scand, 44, 105-122.

27. Murphy JM., Hagey JV., Chigerwe M., 2014. Comparison of serum immunoglobulin $\mathrm{G}$ half-life in dairy calves fed colostrum, colostrum replacer or administered with intravenous bovine plasma. Vet Immunol Immunopathol, 158, 233237.

28. Quigley J., Hammer CJ., Russel LE., Polo J., 2002. Passive immunity in newborn calves. Advances Dairy Tech, 14, 273-292.

29. Güngör Ö., 2006. Newborn calves and colostrum. Kafkas Univ Vet Fak Derg, 12, 103108.

30. Atkinson DJ., Von Keyserlingk MAG., Weary DM., 2017. Benchmarking passive transfer of immunity and growth in dairy calves. J Dairy Sci, 100, 3773-3782.

31. Beam AL., Lombard JE., Kopral CA., Garber LP., Winter AL, Hicks JA., Schlater JL., 2009. Prevalence of failure of passive transfer of immunity in newborn heifer calves and associated management practices on US dairy operations. J Dairy Sci, 92, 3973-3980.

32. Pardon B., Alliet J., Boone R., Roelandt S., Valgaeren B., Deprez P., 2015. Prediction of respiratory disease and diarrhea in veal calves based on immunoglobulin levels and the serostatus for respiratory pathogens measured at arrival. Prev Vet Med, 120, 169-176.

33. Panousis N., Kritsepi-Konstantinou M., Kalaitzakis E., Giadinis N., Valergakis GE., 2013. Prevalence of failure of passive transfer of immunoglobulins in Holstein calves in Northern Greece and association with management practices. J Hellenic Vet Med Soc, 64, 193-200.

34. Lago A., Socha M., Geiger A., Cook D., Silva-delRio N., Blanc C., Leonardi C., 2018. Efficacy of colostrum replacer versus maternal colostrum on immunological status, health, and growth of preweaned dairy calves. J Dairy Sci, 101, 13441354.

35. Morrill KM., Conrad E., Polo J., Lago A., Campbell J., Quigley J., Tyler H., 2012. Estimate of colostral immunoglobulin $G$ concentration using refractometry without or with caprylic acid fractionation. J Dairy Sci, 95, 3987-3996.

36. Hilpert H., Brussow H., Mietens C., Sidoti J., Lerner L., Werchau H., 1987. Use of bovine milk concentrate containing antibody to rotavirus to treat rotavirus gastroenteritis in infants. J Infect Dis, 156, 158-166.

37. McGuirk SM., 2003. Solving calf morbidity and mortality problems. In American Association of Bovine Practitioners, 36th Annual Conference.

38. Windeyer MC., Leslie KE., Godden SM., Hodgins DC., Lissemore KD., LeBlanc SJ., 2014. Factors associated with morbidity, mortality, and growth of dairy heifer calves up to 3 months of age. Prev Vet Med, 113, 231-240.

39. Pagnoncelli MG., De Melo Pereira GV., Fernandes MJ., Tanobe VO., Soccol CR., 2017. Milk Immunoglobulins and Their Implications for Health Promotion.In Nutrients in Dairy and their Implications on Health and Disease Academic Press. pp. 87-96. 
40. Kozat S., 2000. İshalli buzağılarda Kristalloid (Laktatlı Ringer) ve Kolloid+Kristalloid (\%6 Dekstran + Laktatlı Ringer) infuzyon solüsyonlarının rehidratasyon etkinliği. Doktora Tezi, Yüzüncü Yıl Üniversitesi Sağıı Bilimleri Enstitüsü.

41. Tuncay I., Kozat S., 2018. Prevalence of Rotavirus, Coronavirus, Cryptosprodium spp., Escherichia coli K 99, and Giardia lamblia pathogens in neonatal calves with diarrheic in Siirt Region of Turkey. Van Vet J, 29, 17-22.

42. Villarroel A., Miller TB., Johnson ED., Noyes KR., Ward JK., 2013. Factors affecting serum total protein and immunoglobulin $\mathrm{G}$ concentration in replacement dairy calves. Adv Dairy Res, 1, 1-5. 